\title{
The Use of Enzymes in Food Processing: A Review
}

\author{
Sorabh Chaudhary ${ }^{1}$, Sushma Sagar ${ }^{1}$, Mukesh Kumar ${ }^{1}$, R.S. Sengar ${ }^{1}$ and Akash \\ Tomar $^{2}$
}

${ }^{1}$ Department of Agriculture Biotechnology and ${ }^{2}$ Department of Recombinant Techniques Sardar Vallabhbhai Patel University of Agriculture and Technology, Meerut- 250110 (U.P.) *Email:- sorabh.gene@gmail.com,

\begin{abstract}
Enzymes are protein molecules functioning as specialized catalysts for chemical reactions. Enzymes have always been important to food technology because of their ability to act as catalysts, transforming raw materials into improved food products. Food processing enzymes are used as food additives to modify food properties. Food processing enzymes are used in starch processing, meat processing, dairy industry, wine industry and in manufacture of pre-digested foods. The present review extends the frontier of enzyme technology towards food processing applications and discusses the important characteristics of various enzymes and its sources, used in food industries. Various methods of enzyme immobilization for food processing applications have also been discussed in detail.
\end{abstract}

Keywords: Enzymes, Food processing, Food industry, Immobilization, Enzyme technology

Paper cited: Chaudhary, S., Sagar, S., Kumar, M., Sengar, R.S. and Tomar, A. (2015). The use of enzymes in food processing: A review. South Asian Journal of Food Technology and Environment, 1(3\&4): 190-210.

Received: 07/09/2015 Revised: 15/10/2015 Accepted 25/10/2015

\section{Introduction}

The term "enzyme" is derived from the Latin word meaning "in yeast". Enzymes are proteins, produced by living organisms to increase the rate of an immense and diverse set of chemical reactions required for life. In other words, they are highly specific biological catalysts. They are involved in all processes essential for life such as, DNA replication and transcription, protein synthesis, metabolism, cell regulation and signal transduction often via kinases and phosphatases (Hunter, 1995). They are also generate movement, with myosin hydrolysing adenosine triphosphate (ATP) to generate muscle contraction and also moving cargo around the cell as part of the cytoskeleton (Berg et al., 2001). Enzymes are usually named according to the reaction they carry out. Typically, the suffix 'ase' is added to the name of the substrate (e.g. glucoseoxidase, an enzyme which oxidizes glucose) or the type of reaction (e.g. a polymerase or isomerasefor a polymearization or isomerization reaction). The exceptions to this rule are some of the enzymes studies originally, such as pepsin, rennin and trypsin. The International Union Biochemistry (IUB) initiated standards of enzyme nomenclature which recommend that enzymes names indicate both substrates acted upon and the type of reaction catalyzed. Detailed information on nomenclature can be found on the IUB homepage (IUB Homepage). Their ability to perform very specific chemical transformations has made them increasingly useful in industrial processes.

Enzymes have been exploited by human for thousands of years. Food processing through the use of biological agents is historically a well-established approach. The earliest applications go back to $6,000 \mathrm{BC}$ or earlier, with the brewing of beer, bread baking, and cheese and wine making whereas the first purposeful microbial oxidation dates from 2,000 BC, with vinegar production (VasicRacki, 2006; Poulsen and Buchholz, 2003; Schafer et al., 2002). The epoch of classical biotechnology was marked by landmark discoveries of microbes by Leeuwenhook of fermentation as biological processes by Pasteur, of enzymes as protein by Buchner and of the first enzyme crystal structures by summer. In the middle of the nineteenth century, Northrop and Stanley developed a 
complex procedure for isolating pepsin. Their precipitation technique has since been used to crystallize many enzymes. Pectinases were used for juice clarification in the 1930s, and for a short period during World War II, invertases were also used for the production of invert sugar syrup in a process that pioneered the use of immobilized enzymes in the sugar industry (Vasic-Racki, 2006). A few years later, for the first time, an enzyme (a protease) was produced by fermentation of Bacillus licheniformis. In this, way, large-scale production of enzymes became possible, thus facilitating the industrial application of enzymes. Still, the large-scale application of enzymes only became really established in the 1960s, when the traditional acid hydrolysis of starch was replaced by an approach based in the use of amylases and amyloglucosidaes (glucoamylases), a cocktail that some years later would include glucose (xylose) isomearse (Fernandes, 2010a; Leisola, 2002). Enzymes are currently among the well-established products in biotechnology (Norus, 2006), from US $\$ 4.5$ billion to US $\$ 4.8$ billion in 2013 ; it is expected to have reached aroynd US $\$ 7.1$ billion by 2018 , a compound annual growth rate (CAGR) of $8.2 \%$ from 2013 to 2018 (Bon and Ferrara, 2007; World Enzyme Study, 2013). Part of this market is ascribed to enzymes used in large-scale applications, among them are those used in food and feed applications (Binod et al., 2008). These include enzymes used in baking, beverages and brewing, dairy, dairy supplements, as well as fats and oils, and they have typically been dominating one, only bested by the segment assigned to technical enzymes (Berka and Cherry, 2006; Kirk et al., 2002).

\section{Enzymes in Food Processing}

In the twentieth century, enzymes began to be isolated from living cells, leading to a large-scale commercial production and with wider application in the food industry.
Microorganisms are being the most important source of commercial enzymes today. Although they do not contain the same enzymes as plants or animals, a microorganism can usually be found to produce a related enzyme that will catalyze the desired reaction. Enzyme manufacturers have optimized microorganisms for the production of enzymes through natural selection and classical breeding techniques. Food Biotechnology has grown to include cloning of plants and animals, as well as more development in genetically modified foods in more recent years (Agarwal and Sahu, 2014).

Enzymes have always been important to food technology because of their ability to act as catalysts, transforming raw materials into improved food products. The main values of enzymes are their substrate specificity (Ward and Moo-Young, 1988), catalytic effectiveness and a rate enhancement of $10^{10}$ or more over chemical reactions (Burbaun et $a l ., 1989)$ when working under mild conditions of ion concentration, temperature and $\mathrm{pH}$. Enzymes can modify and improve the functional, nutritional and sensory properties of ingredients and products, and therefore enzymes have found widespread applications in processing and production of all kinds of food products. Food technologist selects those enzymes which can improve one particular unit operation of food production. These improvements involve substituting fish protein hydrolysates for milk in calf feed (DiazCastaneda and Brisson, 1989), saving energy and money in production proceses (Christiensen, 1989) and modifying the functional properties of proteins (Adler-Nissen et al., 1983). More and more enzymes for food technology are now derived from specially selected or genetically modified microorganisms grown in industrial scale fermenters and Table 1 enlist the range of examples and applications. About 158 enzymes were used in food industry, 64 enzymes in technical application and 57 enzymes in feedstuff, of which 24 enzymes are 
used in three industrial sectors. Almost $75 \%$ of all industrial enzymes are hydrolytic enzymes. Carbohydrases, proteases and lipases dominate the enzyme market, accounting for more than $70 \%$ of all enzyme sales. Table 2 gives the representative examples of enzyme applications based on different industrial sectors, and discusses the technical benefits in various fields.

\section{(i) Enzymes in Dairy industry}

India being the highest producer of milk in the world, and consequently the surplus availability of milk in our country has triggered the food and dairy industry to convert the liquid milk into value-added products using biochemical and enzymatic processes. The use of rennet in cheese manufacturing was among the earliest applications of exogenous enzymes in food processing. In recent years, proteinases have found additional applications in dairy technology, for example in acceleration of cheese ripening, modification of functional properties and preparation of dietic products (IDF, 1990). Animal rennet (bovine chymosin) is conventionally used as a milk-clotting agent in dairy industry for the manufacture of quality cheeses with good flavour and texture. Rennin acts on the milk protein in two stages, by enzymatic and by non-enzymatic action, resulting in coagulation of milk (Bhoopathy, 1994).

Lactose, the sugar found in milk and whey, and its corresponding hydrolase, lactase or $\beta$-galactosidase, have been extensively researched during the past decade (Mehaiya, 1987). Lactose can be obtained from various sources like plants, animal organs, bacteria, yeasts (intracellular enzyme), or molds. Aminopeptidases are important for the development of flavor in fermented milk products, since they are capable of releasing single amino acid residues from oligopeptides formed by extracellular proteinase activity (Law and Haandrikman, 1997). Proteases and lipases have significant role in dairy food industry. The other minor enzymes having limited applications in dairy processing include glucose oxidase, catalase, superoxide dismutase, sulphydryl oxidase, lactoperoxidase, and lysozymes. Glucose oxidase and catalase are often used together in selected foods for preservation.

Table 1: Enzymes derived from microorganisms and used in food technology

\begin{tabular}{|l|l|l|l|}
\hline Enzyme & Source & Action & Application \\
\hline a-Amylase & $\begin{array}{l}\text { Aspergillus } \text { spp., } \\
\text { Bacillus } \text { spp.* } \\
\text { Microbacterium } \\
\text { irnperiale }\end{array}$ & $\begin{array}{l}\text { Wheat starch } \\
\text { hydrolysis }\end{array}$ & $\begin{array}{l}\text { Dough softening, increased } \\
\text { bread volume, aid } \\
\text { production of sugars for } \\
\text { yeast fermentation }\end{array}$ \\
\hline $\begin{array}{l}\text { Lipase and } \\
\text { Esterase }\end{array}$ & $\begin{array}{l}\text { Aspergillus } \text { spp.*, } \\
\text { Candida } \text { spp., } \\
\text { Rhizomucor miehei, } \\
\text { Penicillium roqueforti, } \\
\text { Rhizopus } \text { spp., } \\
\text { Bacillus } \text { subtilis } *\end{array}$ & $\begin{array}{l}\text { Hydrolyses } \\
\text { triglycerides to } \\
\text { fatty acids and } \\
\text { glycerol; } \\
\text { hydrolyses alkyl } \\
\text { esters to fatty acids } \\
\text { and alcohol }\end{array}$ & $\begin{array}{l}\text { Flavour enhancement in } \\
\text { cheese products; fat } \\
\text { function modification by } \\
\text { interesterification; } \\
\text { synthesis of flavour esters }\end{array}$ \\
\hline $\begin{array}{l}\text { Pectinase } \\
\text { (polygalacturonase) }\end{array}$ & $\begin{array}{l}\text { Aspergillus } \text { spp., } \\
\text { Penicillium } \\
\text { funiculosum }\end{array}$ & Hydrolyses pectin & $\begin{array}{l}\text { Clarification of fruit juices } \\
\text { by depectinization }\end{array}$ \\
\hline
\end{tabular}




\begin{tabular}{|c|c|c|c|}
\hline Pectinesterase & Aspergillus spp.* & $\begin{array}{lr}\text { Removes } & \text { methyl } \\
\text { groups } & \text { from } \\
\text { galacose units in } \\
\text { pectin }\end{array}$ & $\begin{array}{l}\text { With pectinase in } \\
\text { depectinisation technology }\end{array}$ \\
\hline $\begin{array}{l}\text { Hemicellulase and } \\
\text { xylanase }\end{array}$ & $\begin{array}{l}\text { Aspergillus spp.*, } \\
\text { Bacillus subtilis } * \text {, } \\
\text { Trichoderma reesei* }\end{array}$ & $\begin{array}{lr}\text { Hydrolyses } & \text { hemi- } \\
\text { celluloses } & \\
\text { (insoluble } & \text { non- } \\
\text { starch } & \text { poly- } \\
\text { saccharides } & \text { in } \\
\text { flour) } & \end{array}$ & $\begin{array}{l}\text { Bread improvement through } \\
\text { improved crumb structure }\end{array}$ \\
\hline Glucose oxidase & $\begin{array}{l}\text { Aspergillus niger*, } \\
\text { Penicillium } \\
\text { chrysogenum }\end{array}$ & $\begin{array}{l}\text { Oxidises glucose to } \\
\text { gluconic acid }\end{array}$ & $\begin{array}{l}\text { Oxygen removal from food } \\
\text { packaging; removal of } \\
\text { glucose from egg white to } \\
\text { prevent browning }\end{array}$ \\
\hline Glucose isomerase & $\begin{array}{l}\text { Actinplanes } \\
\text { missouriensis, } \\
\text { Bacillus coagulans, } \\
\text { Streptomyces } \\
\text { lividans, }{ }^{*} \\
\text { Streptomyces } \\
\text { rubiginosus }\end{array}$ & $\begin{array}{l}\text { Converts glucose to } \\
\text { fructose }\end{array}$ & $\begin{array}{l}\text { Production of high fructose } \\
\text { corn syrup } \\
\text { (beverage sweetener) }\end{array}$ \\
\hline$\beta$-glucanase & $\begin{array}{l}\text { Aspergillus spp., } \\
\text { Bacillus suhtilis* }\end{array}$ & $\begin{array}{l}\text { Hydrolyses beta- } \\
\text { glucans in beer } \\
\text { mashes }\end{array}$ & $\begin{array}{lll}\text { Filtration } & \text { aids, } & \text { haze } \\
\text { prevention } & \text { in } & \text { beer } \\
\text { production } & & \end{array}$ \\
\hline $\begin{array}{l}\beta \text {-galactosidase } \\
\text { (lactase) }\end{array}$ & $\begin{array}{l}\text { Aspergillus spp., } \\
\text { Kluyvennnves spp. }\end{array}$ & $\begin{array}{l}\text { Hydrolyses milk } \\
\text { lactose to glucose } \\
\text { and galactose }\end{array}$ & $\begin{array}{l}\text { Sweetening milk and whey; } \\
\text { products for lactose- } \\
\text { intolerant individuals; } \\
\text { reduction of crystallisation in } \\
\text { ice cream containing whey; } \\
\text { improving functionality of } \\
\text { whey protein concentration; } \\
\text { manufacture of lactulose }\end{array}$ \\
\hline $\begin{array}{l}\text { Cyclodextrin } \\
\text { glucanotransferase }\end{array}$ & Bacillus spp.* & $\begin{array}{l}\text { Synthesise } \\
\text { cyclodextrins from } \\
\text { liquefied starch }\end{array}$ & \begin{tabular}{ll}
\multicolumn{3}{l}{ Cyclodextrins are food-grade } \\
micro-encapsulants for \\
colours, flavours and \\
vitamins
\end{tabular} \\
\hline Chymosin & $\begin{array}{l}\text { Aspergillus awamori* } \\
\text { Kluyvemmyces lactis* }\end{array}$ & $\begin{array}{l}\text { Hydrolyses kappa- } \\
\text { casein }\end{array}$ & $\begin{array}{l}\text { Coagulation of milk for } \\
\text { cheese making }\end{array}$ \\
\hline $\begin{array}{l}\alpha \text { - Acetoluctute } \\
\text { decarboxylase }\end{array}$ & Bacillus subtilis* & $\begin{array}{l}\text { Converts } \\
\text { acetolactate } \\
\text { acetoin }\end{array}$ & $\begin{array}{l}\text { Reduction of wine } \\
\text { maturation time by } \\
\text { circumventing need for } \\
\text { secondary fermentation of } \\
\text { diacetyl to acetoin }\end{array}$ \\
\hline Cellulase & $\begin{array}{l}\text { Aspergillus niger, } \\
\text { Trichoderma spp. }\end{array}$ & $\begin{array}{l}\text { Hydrolyses } \\
\text { cellulose }\end{array}$ & $\begin{array}{l}\text { Fruit liquifaction in juice } \\
\text { production }\end{array}$ \\
\hline Catalase & $\begin{array}{l}\text { Aspergillus niger* } \\
\text { Micrococcus luteus }\end{array}$ & $\begin{array}{l}\text { Breaks } r \text { down } \\
\text { hydrogen peroxide } \\
\text { to water and } \\
\text { oxygen }\end{array}$ & $\begin{array}{l}\text { Oxygen removal technology, } \\
\text { combined } \\
\text { with glucose oxidase }\end{array}$ \\
\hline
\end{tabular}




\begin{tabular}{|l|l|l|l|}
\hline Aminopeptidase & $\begin{array}{l}\text { Lactococcus lactis, } \\
\text { Aspergillus } \text { spp., } \\
\text { Rhizopus oryzae }\end{array}$ & $\begin{array}{l}\text { Releases free } \\
\text { amino acids from } \\
\text { N-terminus of } \\
\text { proteins and } \\
\text { peptides }\end{array}$ & $\begin{array}{l}\text { De-bittering protein } \\
\text { hydrolysates accelerating } \\
\text { cheese maturation }\end{array}$ \\
\hline Amyloglucosidase & $\begin{array}{l}\text { Aspergillus niger, } \\
\text { Rhizopus } \text { spp. }\end{array}$ & $\begin{array}{l}\text { Hydrolyses starch } \\
\text { dextrins to glucose } \\
\text { (saccharitication) }\end{array}$ & $\begin{array}{l}\text { One stage of high fructose } \\
\text { corn syrup production; } \\
\text { production of Mite' beers }\end{array}$ \\
\hline Pentosanase & $\begin{array}{l}\text { Humicola insolens, } \\
\text { Trichoderma reesei }\end{array}$ & $\begin{array}{l}\text { Hydrolyses } \\
\text { pentosans (soluble } \\
\text { non-starch poly- } \\
\text { saccharides in } \\
\text { wheat flours) }\end{array}$ & $\begin{array}{l}\text { Part of bread dough } \\
\text { improvement technology }\end{array}$ \\
\hline Pullulanase & $\begin{array}{l}\text { Bacillus } \text { spp. } * \\
\text { Klebsiella } \text { spp. } *\end{array}$ & $\begin{array}{l}\text { Hydrolyses 1 -6 } \\
\text { bonds that form } \\
\text { 'branches' in starch } \\
\text { structure }\end{array}$ & $\begin{array}{l}\text { Starch } \\
\text { (improves efficiency) }\end{array}$ \\
\hline $\begin{array}{l}\text { Protease } \\
\text { (proteinase) }\end{array}$ & $\begin{array}{l}\text { Aspergillus } \text { spp. } *, \\
\text { Rhizomucor miehei, } \\
\text { Cryphonectria } \\
\text { parasitica, } \\
\text { Penicillium citrinum, } \\
\text { Rhizopus niveus, } \\
\text { Bacillus } \text { spp. }\end{array}$ & $\begin{array}{l}\text { Hydrolysis of } \\
\text { kappa-casein; } \\
\text { hydrolysis of } \\
\text { animal and } \\
\text { vegetable food } \\
\text { proteins; } \\
\text { hydrolysis of wheat } \\
\text { glutens }\end{array}$ & $\begin{array}{l}\text { Milk coagulation for cheese } \\
\text { making; } \\
\text { hydrolysate production for } \\
\text { soups and savoury foods; } \\
\text { bread dough improvement }\end{array}$ \\
\hline
\end{tabular}

(Source: Whitehust and Law, 2002), *These enzymes are commercially available from GMO versions of the source microorganism.

Table 2: Enzyme application in Food processing

\begin{tabular}{|l|l|l|}
\hline $\begin{array}{l}\text { Application Fields } \\
\text { of Food rocessing }\end{array}$ & Enzymes & \multicolumn{1}{|c|}{ Technical Benefits } \\
\hline $\begin{array}{l}\text { Dairy } \\
\text { Industry }\end{array}$ & $\begin{array}{l}\text { Chymosin, lipases, } \\
\text { lysozymes }\end{array}$ & Cheese manufacturing. \\
\cline { 2 - 3 } & $\beta$-galactosidase, lactases & $\begin{array}{l}\text { Breaking down lactose to glucose and } \\
\text { galactose in milk processing to avoid } \\
\text { lactose intolerance. }\end{array}$ \\
\cline { 2 - 3 } & lactoperoxidase & $\begin{array}{l}\text { Cold sterilisation of milk: milk replacers } \\
\text { for calves }\end{array}$ \\
\cline { 2 - 3 } $\begin{array}{l}\text { Baking } \\
\text { Industry }\end{array}$ & $\begin{array}{l}\text { Milk coagulation } \\
\text { Neutral proteinases and } \\
\text { peptidases }\end{array}$ & $\begin{array}{l}\text { Accelerated cheese ripening; de-bittering; } \\
\text { enzyme modified cheese; production of } \\
\text { hypoallergenic milk-based foods }\end{array}$ \\
\hline \multirow{5}{*}{$\begin{array}{l}\text { Degrading starch in flours and controlling } \\
\text { the volume and crumb structure of bread. }\end{array}$} \\
\cline { 2 - 3 } & $\beta$-xylanases & $\begin{array}{l}\text { Improving dough handling and dough } \\
\text { stability. }\end{array}$ \\
\cline { 2 - 3 } & Oxidoreductase & $\begin{array}{l}\text { Giving increased gluten strength. } \\
\text { dough. }\end{array}$ \\
\cline { 2 - 3 } & Lipases & Reducing the protein in flour \\
\cline { 2 - 3 } & Proteases &
\end{tabular}




\begin{tabular}{|c|c|c|}
\hline & Maltogenic $\alpha$-amylases & Improves self-life of bread and cack \\
\hline & Glucose oxidase & $\begin{array}{l}\text { Oxidative reaction with gluten to make } \\
\text { weak doughs stronger, drive and more } \\
\text { elastic }\end{array}$ \\
\hline & Asparginase & $\begin{array}{l}\text { Reduces the amount of acrylamide formed } \\
\text { during baking }\end{array}$ \\
\hline & Lipoxygenase & Bleaching and strengthening dough \\
\hline \multirow[t]{5}{*}{ Juice industry } & Amylases, glucoamylases & $\begin{array}{l}\text { Breaking down starch into glucose. } \\
\text { Clarifying cloudy juice, especially for } \\
\text { apple juice. }\end{array}$ \\
\hline & Pectinases & $\begin{array}{l}\text { Degrading pectins which are structural } \\
\text { polysaccharides present in cell wall. } \\
\text { Increase the overall juice production. }\end{array}$ \\
\hline & Cellulases, hemicellulose & $\begin{array}{l}\text { Acting on soluble pectin hydrolysis and on } \\
\text { cell wall components with pectinases. } \\
\text { Lowering viscosity and maintenance of } \\
\text { texture. }\end{array}$ \\
\hline & Laccase & $\begin{array}{l}\text { Increasing the susceptibility of browning } \\
\text { during storage. }\end{array}$ \\
\hline & $\begin{array}{l}\text { Naringinase and } \\
\text { limoninase }\end{array}$ & $\begin{array}{l}\text { Acting on compounds that cause bitterness } \\
\text { in citrus juices. }\end{array}$ \\
\hline \multirow[t]{9}{*}{ Starch processing } & $\alpha$-amylases & $\begin{array}{l}\text { Cleaving } \alpha-1,4 \text {-glycosidic bonds in the } \\
\text { inner region of the starch. } \\
\text { Causing a rapid decrease in substrate } \\
\text { molecular weight and viscosity. }\end{array}$ \\
\hline & Pullulanases & $\begin{array}{l}\text { Attacking } \alpha \text {-1, 6-linkage, liberating } \\
\text { straight-chain oligosaccharides of glucose } \\
\text { residues linked by } \alpha-1,4 \text {-bonds. }\end{array}$ \\
\hline & Neopullulanases, & Acting on both $\alpha-1,6$-and $\alpha-1,4$-linkages. \\
\hline & Amylopullulanases & $\begin{array}{l}\text { Cleaving } \alpha-1,4 \text {-linkages fron non- } \\
\text { reducing ends of amylose, amylopectin } \\
\text { and glycogen molecules. }\end{array}$ \\
\hline & $\beta$-amylases & $\begin{array}{l}\text { Producing low-molecular weight } \\
\text { carbohydraetes, such as maltose and " } \beta \text { - } \\
\text { limit dextrin". }\end{array}$ \\
\hline & Glucoamylases & $\begin{array}{l}\text { Attacking } \alpha-1,4 \text {-linkages and } \alpha-1,6- \\
\text { linkages from the non-reducing ends to } \\
\text { release } \beta \text {-d-glucose. }\end{array}$ \\
\hline & Isoamylases & $\begin{array}{l}\text { Hydrolysing } \alpha \text {-1, } 6 \text {-linkages in glycogen } \\
\text { and amylopectin. }\end{array}$ \\
\hline & Glucose isomerases & $\begin{array}{l}\text { Catalysing isomerization of glucose to } \\
\text { fructose. } \\
\text { Transferring a segment of a } 1,4-\alpha-\mathrm{D}- \\
\text { glucan chain to a primary hydroxyl group } \\
\text { in a similar glucan chain to create } 1,6- \\
\text { linkages. }\end{array}$ \\
\hline & Glycosyltransferases & $\begin{array}{l}\text { Increasing the number of branched point to } \\
\text { obtain modified starch with improved } \\
\text { functional properties such as higher } \\
\text { solubility, lower viscosity and reduced } \\
\text { retrogradation. }\end{array}$ \\
\hline
\end{tabular}




\begin{tabular}{|c|c|c|}
\hline \multirow[t]{7}{*}{ Brewing industry } & $\alpha$-amylases & $\begin{array}{l}\text { Hydrolysing starch to reduced viscosity; } \\
\text { Liquefying adjunct; Increasing maltose } \\
\text { and glucose content; }\end{array}$ \\
\hline & $\beta$-glucanases & $\begin{array}{l}\text { Hydrolysing glucans into oligomers and } \\
\text { leading to lower viscosity and better } \\
\text { filterability; Improving wort separation. }\end{array}$ \\
\hline & Pullulanases & $\begin{array}{l}\text { Hydrolysing } \alpha-1,6 \text { branch points of starch. } \\
\text { Securing maximum fermentability of the } \\
\text { wort. }\end{array}$ \\
\hline & Amyloglucosidases & $\begin{array}{l}\text { Increasing glucose content. } \\
\text { Increasing } 1 \% \text { fermentable sugar in "light" } \\
\text { beer. }\end{array}$ \\
\hline & Proteases & $\begin{array}{l}\text { Increasing soluble protein and free amino- } \\
\text { nitrogen (FAN). } \\
\text { Malt improvement. } \\
\text { Improving yeast growth. }\end{array}$ \\
\hline & Pentosanases, xylanases & $\begin{array}{l}\text { Hydrolyzing pentosans of malt, barley and } \\
\text { wheat. } \\
\text { Improving extraction and beer filteration. }\end{array}$ \\
\hline & $\begin{array}{l}\alpha \text {-acetolactate- } \\
\text { decarboxylases (ALDC) }\end{array}$ & $\begin{array}{l}\text { Converting } \alpha \text {-acetolactate to acetoin } \\
\text { directly. } \\
\text { Decreasing fermentation time by avoiding } \\
\text { formation of diacetyl. } \\
\text { Making beer taste right }\end{array}$ \\
\hline \multirow[t]{8}{*}{ Meat processing } & Acid proteases & $\begin{array}{l}\text { Improve flavouring, nutritional and } \\
\text { functional properties of proteins. } \\
\text { Converts animal carcasses into flavourous } \\
\text { compounds under mild condition without } \\
\text { by-product formation. }\end{array}$ \\
\hline & Tyrosinase & $\begin{array}{l}\text { Cross-link meat protein, enhances } \\
\text { functional properties of enzymes. }\end{array}$ \\
\hline & Glutaminase & $\begin{array}{l}\text { Enhances flavour of the meat protein due } \\
\text { to L-glutamic acid. }\end{array}$ \\
\hline & Elastase & $\begin{array}{l}\text { Tenderize meat; improve the commercial } \\
\text { value of the low value meat. }\end{array}$ \\
\hline & Papain/ficin/bromelain & $\begin{array}{l}\text { Meat tenderization. } \\
\text { Hydrolyze both animal and plant proteins. } \\
\text { Increases protein dispersability, } \\
\text { palpability, solubility and digestibility. }\end{array}$ \\
\hline & Transglutaminase & $\begin{array}{l}\text { Improves the structural properties of the } \\
\text { processed or cooked meat. }\end{array}$ \\
\hline & Lipase & $\begin{array}{l}\text { Hydrolyze triglycerides; Improves flavour } \\
\text { in sausages. }\end{array}$ \\
\hline & Actidin & Improve tenderness in processed meat. \\
\hline
\end{tabular}

(Source: Bloom et al., 2005; Fernandes, 2010b; Riberiro et al., 2010) 


\section{(ii) Enzymes in Brewing}

Beer and wine are both alcoholic beverages, produced by yeast fermentation of sugars. Beer is the World's most widely consumed alcoholic beverage; it is the third most popular drink after water and tea (Nelson, 2005). Wine is based on grapes, and beer is traditionally based on barley. The matured grapes already contain the sugars needed for the fermentation, while barley contain starch that has to be broken down to fermentable sugars before the yeast can make alcohol. In the brewing process enzymes have an important role especially starch from leaven that promotes some transformations during the saccharification process. Some enzymes are already present in the barley, e.g. $\beta$-amylases, but the majority of enzymes are produced during the germination, e.g. $\alpha$-amylases and proteases, and in the final malt all the enzymes needed for the conversion of "grains" into a fermentable liquid (wort) is present. The enzymes used in brewing are needed for saccharification of starch (bacterial and fungal $\alpha$-amylases), breakdown of barley $\beta-1,4$ - and $\beta$-1,3- linked glucan ( $\beta$-glucanase) and hydrolysis of protein (neutral protease) to increase the (later) fermentation rate, particularly in the production of high-gravity beer, where extra protein is added (Aastrup et al., 2004). Cellulases are also occasionally used, particularly where wheat is used as adjunct but also to help breakdown the barley $\beta$-glucans. Due to the extreme heat stability of the $B$. amyloliquefaciens $\alpha$-amylase, where this is used the wort must be boiled for a much longer period (e.g. $30 \mathrm{~min}$ ) to inactivate it prior to fermentation. Papain is used in the later post-fermentation stages of beer-making to prevent the occurrence of protein- and tannin-containing 'chill-haze' otherwise formed on cooling the beer. (iii) Enzymes in Potable Alcohol and Wine Production

Wine is the result of the fermentation of grape juice. Enzymes play a pivotal role in the winemaking process. Many of these enzymes originate from the grape itself, the indigenous microflora on the grape and the microorganisms present during winemaking (Table 3). The most widely used enzymes available for commercial use in winemaking are: pectinases, glucanases, xylanases and proteases-to improve the clarification and processing of wine, glycosidase-the release of varietal aromas from precursor compounds, urease-the reduction of ethyl carbamate formation, glucose oxidase-the reduction in alcohol levels (Mojsov, 2013). The main activities currently used in winemaking preparations are derived from the pectinase family. They include pectin lyase (PL), pectin methyl-esterase (PME) and polygalacturonase (PG). Food grade industrial enzymes offer significant processing improvements. These result in overall economic benefits. Industrial enzymes offer quantitative benefits as increased free run and press juice yields. The qualitative benefits as improved color extraction in red grape varieties, color stability and phenolic extraction of red wines (Bucelli, 2006; Ducasse et al., 2010; Main and Morris, 2007; Parley et al., 2001; Romero-Cascales et al., 2008; Watson et al., 1999b), and improvements in the aging process of wines, i.e. flavor enhancement. Processing benefits resulted in shorten the time of maceration, settling, and filtration (Canal-Llaubères, 1989; Capaunova and Drdak, 2002; Plank and Zent, 1993; Revila and Gonzàlez-SanJosé, 2002; Rogerson et al., 2000; Villettaz and Dubourdien, 1991).

The pectic enzymes play an important role in braking down grape pulp and skin cells and are able to split those chains and 
saccharide bonds between the chains (Whitaker, 1984). The first commercial enzyme preparations used in wine industry consisted of pectinase (Rombouts and Pilnik, 1980). Today, pectic enzymes alone account for about one-quarter of the world's food enzyme production. Most commercial preparations of pectic enzymes are obtained from fungal sources (Alkorta et al., 1994). In red wine, tannins and anthocyanins are the most important phenolic classes. Tannins contribute to the mouthfeel of wines but they also form pigmented polymers in association with the anthocyanins to provide the stable pigments required to give red wine its long term colour stability. Grape anthocyanins are red pigments, located in the first external layers of the hypodermal tissue and mainly in the vacuoles (Barcelo et al., 1994), as well as in special structures called anthocyanoplasts (Pecket and Small, 1980).

Table 3: Enzymes derived from grapes and wine associated microbes involved in winemaking

\begin{tabular}{|c|c|c|}
\hline Source & Enzyme & Remark \\
\hline $\begin{array}{l}\text { Grape } \\
\text { vinifera) }\end{array}$ & $\begin{array}{l}\text { Glycosidases } \\
\text { Protopectinases } \\
\text { Pectin } \\
\text { methylesterases } \\
\text { Polygalacturonases } \\
\text { Pectin lyases } \\
\text { Proteases } \\
\text { Peroxidases } \\
\text { Tyrosinases (oxido- } \\
\text { reductases) }\end{array}$ & $\begin{array}{l}\text { Hydrolyse sugar conjugates of tertiary alcohols; } \\
\text { inhibited by glucose; optimum pH 5-6 } \\
\text { Produce water-soluble, highly polymerized pectin } \\
\text { substances from protopectins } \\
\text { Saponifying enzymes that split metyl ester groups of } \\
\text { polygalacturonic acids thereby releasing methanol and } \\
\text { converting pectin into pectate; thermostable; optimum } \\
\text { pH 7-8 } \\
\text { Hydrolyse } \alpha \text {-D-1,4-glycosidic linkages adjacent to a } \\
\text { free carboxyl group in low methylated pectins and } \\
\text { pectate; optimum pH } 4-5 \\
\text { Depolymerise highly esterified pectins } \\
\text { Hydrolyse the peptide linkages between the amino acid } \\
\text { residues of proteins; inhibited by ethanol; } \\
\text { thermostable; optimum pH } 2 \\
\text { Play an important role in the oxidation metabolism of } \\
\text { phenolic compounds during grape maturation; activity } \\
\text { is limited by peroxide deficiency and sulphur dioxide } \\
\text { in must } \\
\text { Oxidise phenols into quinones resulting in undesirable } \\
\text { browning }\end{array}$ \\
\hline $\begin{array}{l}\text { Fungi (Botrytis } \\
\text { cinerea) }\end{array}$ & $\begin{array}{l}\text { Glycosidases } \\
\text { Laccases } \\
\text { Pectinases } \\
\text { Cellulases }\end{array}$ & $\begin{array}{l}\text { Degrades all aromatic potential of fungal infected } \\
\text { grapes } \\
\text { Broad specificity towards phenolic compounds and } \\
\text { cause serious oxidation and browning problems } \\
\text { Saponifying and depolymerising enzymes causing the } \\
\text { degradation of plant cell walls and grape rotting } \\
\text { Multicomponent complexes comprising } \\
\text { endoglucanases, exoglucanases (cellobiohydrolases) } \\
\text { and cellobiases (a member of } \beta \text {-glucosidases) that act } \\
\text { synergistically in a stepwise process to degrade plant } \\
\text { cell walls thereby causing grape rotting } \\
\text { Degrades phospholipids in cell membranes } \\
\text { Involved in ester formation } \\
\text { Aspartic proteases are produced at the early stage of }\end{array}$ \\
\hline
\end{tabular}




\begin{tabular}{|c|c|c|}
\hline & $\begin{array}{l}\text { Phospholipase } \\
\text { Esterases } \\
\text { Proteases }\end{array}$ & $\begin{array}{l}\text { fungal infection of grapes and determine the } \\
\text { subsequent rate and extent of rotting caused by } \\
\text { pectinases; soluble; thermostable }\end{array}$ \\
\hline $\begin{array}{l}\text { Yeast } \\
\text { (Saccharomyces } \\
\text { cerevisiae) }\end{array}$ & $\begin{array}{l}\beta \text {-Glucosidases } \\
\beta \text {-Glucanases } \\
\text { Proteases } \\
\text { Pectinases }\end{array}$ & $\begin{array}{l}\text { Some yeasts produce } \beta \text {-glucosidases which are not } \\
\text { repressed by glucose } \\
\text { Consist of extracellular, cell wall bound and } \\
\text { intracellular, sporulation specific glucanases; } \\
\text { accelerate autolysis process and release } \\
\text { mannoproteins } \\
\text { Acidic endoprotease; Accelerates autolysis process } \\
\text { Some yeasts degrade pectic substances to a limited } \\
\text { extent; inhibited glucose levels higher than } 2 \%\end{array}$ \\
\hline $\begin{array}{l}\text { Bacterial (Lactic } \\
\text { acid bacteria) }\end{array}$ & $\begin{array}{l}\text { Malolactic enzymes } \\
\text { Esterases } \\
\text { Lipolytic enzymes }\end{array}$ & $\begin{array}{l}\text { Convert malic acid to lactic acid } \\
\text { Involved in ester formation } \\
\text { Degrade lipids }\end{array}$ \\
\hline
\end{tabular}

(van Rensburg and Pretorius, 2000 and Adapted from the Freedonia Group Inc., World Enzymes to 2015)

\section{(iv) Enzymes in Bakery Technology}

The development of bread process was an important event in mankind. After the 19th century, with the agricultural mechanization, bread's quality was increased while its price was reduced; thereby white- and rye-bread became a commodity within almost everyone's reach. An important aspect that contributed to evolution of the baking market was the introduction of industrial enzymes in the baking process, where bakery enzymes represent a relevant segment of the industry. Table 4 summarizes the world bakery and enzyme demand between 2000 and 2020, segmented according to products. It is possible to observe that the enzymes market for baked goods is expected to increase from 420 million dollars in 2010 to 900 million dollars in 2020 , although maintaining its representativeness in this segment, varying from 34.4 in 2010 to $35.7 \%$ in 2020 (The Freedonia Group, Inc ).

Baking comprises the use of enzymes from three sources: the endogenous enzymes in flour, enzymes associated with the metabolic activity of the dominant microorganisms and exogenous enzymes which are added in the dough (Di Cagno, 2003). The supplementation of flour and dough with enzyme improvers (technical enzymes) is a usual practice for flour standardization and also as baking aids. Enzymes are usually added to modify dough rheology, gas retention and crumb softness in bread manufacture, to modify dough rheology in the manufacture of pastry and biscuits, to change product softness in cake making and to reduce acrylamide formation in bakery products (Cauvain and Young, 2006). The enzymes can be added individually or in complex mixtures, which may act in a synergistic way in the production of baked goods (Di Cagno et al., 2003; Collar, 2000; Martinez-Anaya and Jimenez, 1997), and their levels are usually very low.

Enzymes as technological aids are usually added to flour, during the mixing step of the breadmaking process. The enzymes most frequently used in breadmaking are the 
$\alpha$-amylases from different origins (Sanz Penella et al., 2008). Amylases can degrade starch and produce small dextrins for the yeast to act upon. Enzymes such as hemicellulases, xylanases, lipases and oxidases can directly or indirectly improve the strength of the gluten network and so improve the quality of the finished bread.

Table 4: Estimated demand (million dollars) of baked goods, dairy and other food $\&$ beverage enzymes

\begin{tabular}{|l|c|c|c|c|c|}
\hline \multirow{2}{*}{ Items } & \multicolumn{5}{c|}{ Year } \\
\cline { 2 - 6 } & $\mathbf{2 0 0 0}$ & $\mathbf{2 0 0 5}$ & $\mathbf{2 0 1 0}$ & $\mathbf{2 0 1 5}$ & $\mathbf{2 0 2 0}$ \\
\hline World food and beverage enzyme demand & 520 & 760 & 1220 & 1770 & 2520 \\
\hline Baked goods & 140 & 250 & 420 & 625 & 900 \\
\hline Dairy & 180 & 260 & 360 & 465 & 610 \\
\hline Other foods and beverage & 200 & 250 & 440 & 680 & 1010 \\
\hline
\end{tabular}

The addition of certain types of pentosanases or xylanases at the correct dosage can improve dough machinability yielding more flexible, easier-to-handle dough. The addition of functional lipases modifies the natural flour lipids so they become better at stabilizing the dough. The addition of lipases has been claimed to retard the rate of staling in baked products (Cauvain and Young, 2006; Johnson and Welch, 1968; Siswoyo et al., 1999). Lipoxygenases are also employed to improve mixing tolerance and dough handling properties (Cumbee et al., 1997). The action of lipoxygenase can lead to undesirable flavors in bread (Linko et al., 1997; Stauffer, 1990). Glucose oxidase can be used as alternative oxidizing agent instead of potassium bromate in breadmaking. Addition of increasing glucose oxidase concentrations to wheat flour dough produced significant changes on dough rheology and bread quality; and the extent of the effect was highly dependent on the amount of enzyme and the original wheat flour quality (Bonet et al., 2006). Furthermore, glucose oxidase was able to recover the breadmaking ability of damaged gluten (Bonet et al., 2007). Asparaginase is claimed to have a high potential of reducing formation of acrylamide during baking (Anese et al., 2011; Capuano et al., 2008; Bråthen and Knutsen, 2005).

\section{(v) Enzymes in Fruit and Vegetable Processing and Juice Extraction}

India is the second largest producer of fruits and vegetables after china. Total production of fruits during 2012-13 was 81.2 million tonnes while that of vegetables was 162 million tonnes whereas the second advance estimates put the production at 84.4million tonnes and $\mathbf{1 7 0 . 2}$ million tonnes respectively for 2013-14 (Hand book on Horticulture Statistics, 2014). The expansion of the global fruit and vegetable juice industry is forecast to reach $3.7 \%$ p.a. in the coming years. Between 2007 and 2013 the market increased with an average annual growth of 3.5\%. China, France, Germany, the United Kingdom and the United States represent the largest fruit and vegetable juice markets while the strongest annual growth is forecast to occur in Morocco (30.5\%), India (18.0\%), 
Rwanda (17.0\%), Egypt (13.8\%) and Moldova $(12.0 \%)$ (Fruit and Vegetable juice market, 2014).

Enzymes are processing aids used worldwide for fruit processing, particularly for the production of clear fruit juice and concentrate. Enzymes can increase the yield of solid recovery during pulp washing, facilitate the production of highly concentrated citrus bases, improve essential oil recovery from peel, debitter juice, clarify lemon juice or increase the worth of waste products (Grassin and Fauquembergue, 1996). Pectinases are one of the important upcoming enzymes of the commercial sector especially for fruit juice industry as prerequisites for obtaining well clarified and stable juices with higher yields (Dupaigne, 1974; Tocchini and Lara, 1977; Jaleel et al., 1978; Viquez et al., 1981; Girard and Fukumoto, 1999; Lee et al., 2006; Sandri et al., 2012). Other enzymes used in the juice industry are amylases, glucoamylases, cellulases, hemicellulose, laccase, naringinase and limoninase. Amylases are added together with pectinases at the start of the processing season when apples contain starch. Vegetable juice processing therefore requires more cellulases in addition to pectinases to reduce viscosity sufficiently for juice extraction using a decanter. Peclyve LI (Lyven) or Rapidase Vegetable Juice (DSM) is recommended for vegetable juice extraction: they contain pectinases and cellulases.

\section{(vi) Enzymes in Meat Processing}

Tenderness of meat is considered as the most important quality distinguishing feature of meat in consumer evaluation (Koohma-raie, 1994, 1996; Boleman et al., 1995; Miller et al., 2001; Koohmaraie and Geesink, 2006; Destefanis et al., 2008; Zor, K. et al., 2009). Tenderness in meat results from a combination of breakdown within muscle fibres, primarily because of the activity of enzymes, and loosening of connective tissue, in particular collagen. Various pre-slaughter and post-slaughter factors and their mutual effect influence tenderness of meat (Destefanis et al., 2008). In meat industry and catering predominantly protein-degrading enzymes have been used. Of the protein cross-linking enzymes, transglutaminases (TGase) have been used as texture improvers already for several years. Structure engineering by oxidative enzymes and flavour design by lipases, glutaminases, proteases and peptidases are examples of emerging enzyme technologies in the food sector (Whitehurst and van Oort, 2010). One of the potential areas in meat processing is meat tenderizing using enzymes such as papain and bromelain derived from plant sources such as papaya and pine apple plant, respectively. Toughness of meat is generally due to the presence of collagen, elastin and actomycin. Meat cuts that are considered as lower quality due to toughness are as nutritious as prime quality meat, which can be tenderized using enzymes to convert it to prime quality meat. Even the flavour of the meat depends on the peptides and the amino acids present in meat. Enzymes such as proteases are utilized for tenderization and marination. Proteases can be applied for production of protein hydrolyzates from different meat by-products such as bones (Vollmer and Rosenfield, 1983), sheep visceral mass (Bhaskar et al., 2007), chicken byproducts (Surowka and Fik, 1994) or bovine by-products (Webster et al., 1882).

\section{(vii) Enzymes in Starch Processing}

Starch is a widely used renewable resource. It is present as a storage compound in the leaves, tubers, seeds and roots of many plants. The starch is usually modified chemically or enzymatically to a wide variety of derivatives. The industrial degradation of starch is usually initiated by $\alpha$-amylases $(\alpha-1$, 
4-glucanohydrolases) a very common enzymes in micro-organisms. Together with other starch-degrading enzymes (eg. Pullulanases), $\alpha$-amylases are included in family 13 of glycosyl hydrolases (Hanrissat and Bairoch, 1996). Pullulanases specifically attack $\alpha-1,6-$ linkages, liberating linear oligosaccharides of glucose residues linked by $\alpha-1$, 4-bonds. Pullulanases are divided into type $I$ that exclusively hydrolyze $\alpha-1,6$ linkages and produce branched dextrins, and type II that hydrolyze both $\alpha-1,4$ and $\alpha-1,6$ linkages and produce mainly maltose and maltotriose (Doman-Pytka and Bardowski, 2004). These enzymes specifically hydrolyze the $\alpha-1,6$ glycosidic linkages in amylopectin or glycogen but they do not show any activity towards pullulan (Yokobayashi et al., 1970; Amemura et al., 1988).

There are three basic steps in the enzymatic conversion of starch: gelatinization, liquefaction and saccharification. Two types of exo-acting hydrolases are commonly used for starch saccharification: $\beta$-amylases and glucoamylases. $\beta$-amylases are unable to cleave $\alpha-1$, 6-linkages and the final product consists of maltose and " $\beta$-limit dextrin". Thus degradation of amylopectin is incomplete. Glucoamylases cleave preferentially $\alpha-1,4-$ linkages and can also cleave $\alpha-1,6$-glycosidic linkages at a much lower rate. As a consequence, glucoamylases have the ability to carry out almost complete degradation of starch into glucose (Synowiecki, 2007). The isomerisation of starch-derived glucose leads to greater sweetness of the obtained syrup which is commonly used in many food and beverage products. Fructose syrups are usually made in a continuous process catalysed by immobilized glucose (xylose) isomerase. In order to produce the syrup containing the standard concentration (55\%) of fructose, cation-exchange fractionation of carbohydrate is used (Crabb and Mitchinson, 1997). Maltose can be converted into isomaltooligosaccharides (IMO) using specific $\alpha$ glucosidases. These are exo-acting enzymes that hydrolyze amylose, amylopectin and oligosaccharides including maltose from the non-reducing end producing glucose (Whitehurst and Oort, 2010).

\section{Immobilized Enzyme Technology for Food Application}

There are very few examples of commercial food processing operations that use immobilized enzymes currently, despite their introduction in the 1970s. Immobilization generally reduces the enzyme's activity and the enzymes are subject to mass transfer limitations. The cost of the matrix and support and regenerative capability of the biocatalyst also contribute to the cost of the immobilized enzyme process. Immobilization can be performed by several methods, namely, entrapment/ microencapsulation, binding to a solid carrier, and cross-linking of enzyme aggregates, resulting in carrier-free macromolecules (Sheldon, 2007). Immobilized enzymes are of great value in the processing of food samples and its analysis. The extent of lactose hydrolysis whey processing, skimmed milk production, etc. has been greatly enhanced by using respective enzymes as immobilized forms. The production of high fructose corn syrup has been greatly facilitated by the use of immobilized glucose isomerase. A relatively new concept is the use of a single matrix for immobilizing more than one enzyme to enhance food processing. Two of the most successful examples of immobilized enzymes are the production of high-fructose corn syrup and the enzymatic modification of oils. Immobilized lipases are used as alternatives to hydrogenation and non-specific chemical esterification of oils to produce transfat free margarines and shortening, cocoa butter equivalents, medium chain 
triacylglycerols, diacylglycerols, fatty acid esters, and tailored fat products (Betapol®). The use of lipases in the immobilized form, versus sodium methylate, allows for oil modifications in solvent free systems, specificity in the modification and the products need minimal post treatment purification. Previous commercial processes that used immobilized enzymes include $\beta$-galactosidase for production of lactose hydrolyzed whey syrups and immobilized amylase for production of L-aspartic acid. Pilot scale processes have been developed including the production of 5'-ribonucleotides using immobilized 5'-phosphodisterase, production of isomaltulose using immobilized isomaltulose synthase, sucrose hydrolysis using immobilized invertase and aspartame synthesis using immobilized thermolysin.

Immobilized multi-enzyme system offer many attractive advantages however, such a process also raises some interesting questions about kinetics. Compared to the free enzyme, the higher activity of the immobilized enzyme at the higher temperature and the ability to hydrolyze raw starch such as that of potato would help overcome problems related to gelatinization of starch during hydrolysis (Gangadharan et al., 2009). Table 5 summarize the processing of various food substrates using respective immobilized enzymes.

Table 5: Immobilized enzymes used in food industry

\begin{tabular}{|l|l|l|l|}
\hline Enzyme & $\begin{array}{l}\text { Immobilization } \\
\text { support }\end{array}$ & Food substrate & References \\
\hline $\begin{array}{l}\beta \text {-galactosidase and } \\
\text { amyloglucosidase }\end{array}$ & Bone powder & $\begin{array}{l}\text { Lactose, whey, whey } \\
\text { permeates, skimmed milk }\end{array}$ & Carpio et al., 2000 \\
\hline Pectinase & Anion exchange resin & Pectin & Sarioglu et al., 2001 \\
\hline Laccase & Silica gel & $\begin{array}{l}\text { Wine, fruit juice and beer } \\
\text { processing }\end{array}$ & Minussi et al., 2002 \\
\hline Trypsin & Cellulose & $\beta$-lactoglobulin & Yamamoto et al., 2005 \\
\hline $\begin{array}{l}\text { Cardosin-A } \\
\text { protease) }\end{array}$ & Agarose glutarldehyde & $\alpha$-lactalbumin & Barros et al., 2003 \\
\hline Pectin lyase & Alginate beads & Esterified pectin & Busto et al., 2006 \\
\hline Tyrosinase & $\begin{array}{l}\text { Polyacrylic-acid carbon } \\
\text { nanotubes }\end{array}$ & Phenolic in red wine & Kim et al., 2010 \\
\hline$\beta$-galactosidase & $\begin{array}{l}\text { Organic and inorganic } \\
\text { support }\end{array}$ & $\begin{array}{l}\text { Removal of lactose from } \\
\text { milk }\end{array}$ & Husain et al., 2010 \\
\hline Lipase & Calcium-alginate beads & Oil and grease & Jeganathan et al., 2006 \\
\hline Pectinase & Anion-exchange resin & Pectin solution & Sarioglu et al., 2001 \\
\hline$\beta$-galactosidase & Duolite A-568 & Muscat wine & Gueguen et al., 1997 \\
\hline Glucoamylase & Chitin & $\begin{array}{l}\text { Starch and hydrolyzed } \\
\text { mannose starch }\end{array}$ & $\begin{array}{l}\text { Freire and } \text { sant'Anna, } \\
1990\end{array}$ \\
\hline
\end{tabular}




\section{Conclusion and perspectives}

The use of enzymes in the food industry is a well-established approach, in particular due to the specificity of enzyme action and their green, environmentally friendly nature. As mentioned above, enzymes are currently used in several different food products and processes and new areas of application are constantly being added. The introduction of enzymes as effective biocatalysts working under mild conditions results in significant saving in resources such as energy and the environment. Evidence clearly shows that dedicated research efforts are consistently being made as to make this application of biological agents more effective and diversified. These endeavours have been anchoring in innovative approaches for the design of new/improved biocatalysts, more stable, less dependent on metal ions and less susceptible to inhibitory agents and to aggressive environmental conditions, while maintaining the targeted activity or evolving novel activities. This is a particular relevance for application in the food sector, for it allows enhanced performance under operational conditions that minimize the risk of microbial contamination. Immobilization of enzymes has been a key supporting tool for rendering these proteins fit for food application, while simultaneously enabling the improvement of their catalytic features. Again, and despite the developments made in this particular field, there is still the lack of a set of unanimously applicable rules for the selection of carrier and method of enzyme immobilization. In a world with a rapidly increasing population and approaching exhaustion of many natural resources, enzyme technology offer a great potential for many food industries to help meet the challenges they will face in years to come.

\section{References}

1. Aastrup, S., Noel, B., Elmer, J. and Kurt, D. (2004). Choice of Enzyme Solution Should Determine Choice of Raw Materials and Process, Presentation Given at World Brewing Conference, San Diego.

2. Adler-Nissen, J., Eriksen, S. and Olsen, H. (1983). Improvement of the functionality of vegetable proteins by controlled enzymatic hydrolysis. Plant Foods and Human Nutrition, 32: 411423.

3. Agarwal, S. and Sahu, S. (2014). Safety and Regulatory Aspects of Food Enzymes: An Industrial Perspective. International Journal Interdisciplinary and multidisciplinary Studies, 1: 253-267.

4. Alkorta, I., Lama, M. J., and Serra, J. L. (1994). Interference by pectin in protein determination. Food Science and Technology, 27: 39-41.

5. Amemura, A., Chakrabotry, R., Fujita, M., Noumi, T. and Futai, M. (1988) Cloning and nucleotide sequencing of the isoamylase gene from Pseudomonas amyloderamosa SB-15. Journal of Biological Chemistry, 263: 9271-9275.

6. Anese, M., Quarta, B. and Frias, J. (2011). Modelling the effect of asparaginase in reducing acrylamide formation in biscuits. Food Chemistry, 126: 435-440.

7. Barcelo, A. R., Calderon, A. A., Zapata, J. M. and Munoz, R. (1994). The histochemical localization of anthocyanins in seeded and seedless grapes (Vitis vinifera). Scientia Horticulturae, 57: 265-268.

8. Barros, R. M., Extremina, C. I., Goncalves, I. C., Braga, B. O., Balcao, V. M. and Malcata, F. X. (2003). Hydrolysis of $\alpha$-lactalbumin by cardosin A immobilized on highly activated support. Enzyme and Microbial Technology, 33: 908-916

9. Berg, J.S., Powell, B.C. and Cheney, R.E. (2001) A millennial myosin 
census. Molecular Biology of the Cell, 12(4): 780-794.

10. Berka, R. M. and. Cherry, J. R. (2006). Enzyme biotechnology, In: Basic Biotechnology, C. Ratledge and B. Kristiansen, (Eds.), 477-498, Cambridge University Press, Cambridge, UK, $3^{\text {rd }}$ edition.

11. Bhaskar, N., Modi, V.K., Govindaraju, K., Radha, C. and Lalitha, R.G. (2007) Utilization of meat industry by products: protein hydrolyzate from sheep visceral mass. Bioresource Technology, 98: 388-394.

12. Bhoopathy, R., 1994. Enzyme technology in food and health industries. Indian Food Industry, 13: 22-31

13. Binod, P., Singhania, R. R., Soccol, C. R. and Pandey, A. (2008). Industrial enzymes, In: Pandey, A., Larroche, C., Soccol, C. R. and Dussap, C.G. (Eds.), Advances in Fermentation Technology. Asiatech Publishers, New Delhi, India. pp. 291-320,

14. Bloom, J. D., Meyer, M. M., Meinhold, P., Otey, C. R., MacMillan, D. and Arnold, F. H. (2005). Evolving strategies for enzyme engineering. Current Opinion Structural Biology, 15: 447-452

15. Boleman, S. J., Boleman, s. 1., Binder, T. D., Mc Millin, K. W. and Monlezun, C. J. (1995). Effect of postmortem time of calcium chloride injection on beef tenderness and drip, sooking and total loss. Meat Science, 39: $35-41$

16. Bon, E. P.S. and Ferrara, M. A. (2007). Bioethanol production via enzymatic hydrolysis of cellulosic biomass, Document prepared for "The Role of Agricultural Biotechnologies for Production of Bioenergy in Developing Countries" an FAO seminar held in Rome on 12 October 2007, http://www.fao.org/biotech/seminaroct 2007.htm.
17. Bonet, A., Rosell, C. M, Caballero, P. A, Gomez, M., Perez-Munuera, I. and Lluch, M. A. (2006). Glucose oxidase effect on dough rheology and bread quality: a study from macroscopic to molecular level. Food Chemistry, 99: 408-415

18. Bonet, A., Rosell, C. M., PerezMunuera, I. and Hernando, I. (2007). Rebuilding gluten network of damaged wheat by means of glucose oxidase treatment. Journal of the Science of Food and Agriculture, 87: 1301-1307

19. Bråthen, E. and Knutsen, S. H. (2005). Effect of temperature and time on the formation of acrylamide in starchbased and cereal model systems, flat breads and bread. Food Chemistry, 92: 693-700

20. Bucelli, P., Piracci, A., Faviere, V., Giannetti, F., Scotti, B., Bergaglio, F. (2006). Effect of the application of maceration enzymes on red wine colour stability, The Australian \& New Zealand Grape grower and Winemaker, Nov., 2006, 71-77.

21. Burbaum J., Raines R., Albery W. and Knowles J. (1989) Evolutionary optimization of the catalytic effectiveness of an enzyme. Biochemistry, 28: 9293-9305.

22. Busto, M. D., Garcia-Tramontin, K. E., Ortega, N. and Perez-Mateos, M. (2006). Preparation and properties of an immobilized pectinlyase for the treatment of fruit juices. Bioresource Technology, 97: 1477-1483

23. Canal-Llaubères, R. M. (1989). Enzyme in winemaking, In: Fleet, G. H. (Eds), Wine Microbiology and Biotechnology. Harwood Academic Publishers, Philadelphia.

24. Capounova, D. and Drdak, M. (2002). Comparison of some Commercial Pectic Enzyme Preparations Applicable in Wine Technology. Czech Journal of Food Science, 20: 131-134.

25. Caprio, C., Gonzalez, P., Ruales, J. and Bastista, F. (2000). Bone-bound 
enzymes for food industry application. Food Chemistry, 68: 403-409

26. Capuano, E., Ferrigno, A., Acampa, I., Serpen, A., Açar, Ö. Ç., Gökmen, V. and Fogliano, V. (2008). Effect of flour type on Maillard reaction and acrylamide formation during toasting of bread crisp model systems and mitigation strategies. Food Research International, 42: 1295-1302.

27. Cauvain, S., and Young, L. (2006). Ingredients and their influences. In: Cauvain S, Young L. (Eds.), Baked Products. Science, Technology and Practice. Oxford: Blackwell Publishing; pp. 72-98

28. Christensen, F. (1989). Enzyme technology versus engineering technology in the food industry. Biotechnology and Applied Biochemistry, 11: 249-265

29. Collar, C., Martinez, J. C., Andreu, P. and Armero, E. (2000). Effects of enzymes associations on bread dough performance. A response surface analysis. Food Science and Technology International, 6: 217-226

30. Cover, S., Hostetler, R. L. and Ritchey, S. J. (1962). Tenderness of beef, IV. Relation of shear force and fiber extensibility to juiciness and six components of tenderness. Journal Food Science, 27: 527-536.

31. Crabb, D. W. and Mitchinson, C. (1997). Enzymes involved in the processing of starch to sugar. TIBTECH, 15: 349-353.

32. Cumbee, B., Hildebrand, D. F. and Addo, K. (1997). Soybean flour lipoxygenase isozymes effects on wheat flour dough rheological and breadmaking properties. Journal of Food Science, 62: 281-283

33. Destefanis, G., Brugiapaglia, A., Barge, M. T. and Dal Molin, E. (2008). Relationship between beef consumer tenderness perception and Warner-Bratzler shear force. Meat Science, 78: 153-156.

34. Di Cagno, R., De Angelis, M., Corsettic, A., Lavermicocca, P.,
Arnault, P., Tossut, P., Gallo, G. and Gobbetti, M. (2003). Interactions between sourdough lactic acid bacteria and exogenous enzymes: effects on the microbial kinetics of acidification and dough textural properties. Food Microbiology, 1: 67-75.

35. Diaz-Casteneda, M. and Brisson, G. (1989). Blood responses of calves fed milk substitutes containing hydrolysed fish protein and lime-treated corn flour. Journal of Dairy Science, 72: 2095-2106.

36. Doman-Pytka, M. and Bardowski, J. (2004) Pullulan degrading enzymes of bacterial origin. Critical Reviews in Microbiology, 30: 107-121.

37. Ducasse, M. A., Canal-Llauberes, R. M., de Lumley, M., Doco, T., Cheynier, V. (2010). Effect of macerating enzyme treatment on the polyphenol and polysaccharide composition of red wines. Food Chemistry, 2: 369-376.

38. Dupaign, P. (1974). The aroma of bananas. Fruits, 30: 783-789

39. Fernandes, P. (2010a). Enzymes in sugar industries, In: Panesar, P., Marwaha, S. S. and Chopra, H. K. (Eds.), Enzymes in Food Processing: Fundamentals and Potential Applications. I.K. International Publishing House, New Delhi, India. pp. 165-197,

40. Fernandes, P. (2010b). Enzymes in Food Processing: A Condensed Overview on Strategies for Better Biocatalysts. Enzyme Research, 19.

41. Freedonia Group Inc. World Enzymes-Industry Study with Forecasts for 2013 \& 2018: Study \#2506, August 2009, http://www.freedoniagroup.com/broch ure $/ 25 \mathrm{xx} / 2506$ smwe.pdf.

42. Freire, D. G. and Sant'Anna Jr., G. L. (1990). Characterization of a glucoamylase immobilized on chitin. Biomass, 23: 71-78

43. Fruit and Vegetable Juice Markets in the world to 2018- market size, Trends and Forecasts. 
44. http://www.reportlinker.com/p021701

38/Fruit-and-Vegetable-Juice-

Markets-in-the-World-to-2018---

Market-Size-Trends-and-

Forecasts.html (accessed on 10

January 2014)

45. Gangadharan, D., Nampoothiri, K. M., Sivaramakrishnan, S. and Panday, A. (2009). Immobilized bacterial $\alpha$ amylase for effective hydrolysis of raw and soluble starch. Food Research International, 42: 436-442

46. Girard, B. and Fukumoto, L. R. (1999). Apple juice clarification using microfiltration and ultrafiltration polymeric membranes. LebensmittelWissenschaft und-Technologie- Food Science and Technology, 32: 290-298

47. Grassin, C., and Fauquembergue, P. (1996). Fruit juices. In: Godfrey, T., West, S. (Eds), Industrial Enzymology $\left(2^{\text {nd }}\right.$ edn). Macmillan, London. pp. 227.

48. Gueguen, Y., Chemardin, P., Pien, S., Amaud, A., and Galzy, P. (1997). Enhancement of aromatic quality of Muscat wine by the use of immobilized $\beta$-glucosidase. Journal of Biotechnology, 55: 151-156

49. Hand Book on Horticulture Statistics, (2014). Govt. of India, Ministry of Agriculture, New Delhi.

50. Hanrissat, B and Bairoch, A. (1996). Updating the sequence-based classification of glycosyl hydrolases. Biochemistry Journal, 316: 695-696.

51. Hunter, T. (1995). Protein kinases and phosphatases: the yin and yang of protein phosphorylation and signaling. Cell, 80: 225-236.

52. Husain, Q. (2010). Beta galactosidase and their potential application: A review. Critical Reviews in Biotechnology, 30: 41-62

53. IDF, Int. Dairy Fed. Bull., (1990). 247: 24-38

54. IUB homepage, http://www.chem.qmul.ac.uk/iubmb/

55. Jaleel, S. A., Basappa, S. C. and Sreekantiah, K. R. (1978). Developmental studies on certain aspects of enzymic processing of banana I. Laboratory investigations. Indian Food Packer, 32: 17-21

56. Jeganathan, J., Bassi, A. and Nakhla, G. (2006). Pre-treatment of high oil and grease pet food industrial wastewaters using immobilized lipase hydrolyzation. Journal of Hazardous Materials, 137: 121-128

57. Johnson, R.H, and Welch, E.A. (1968).. Baked goods dough and method. US Patent Application; US 3,368,903.

58. Kim, O., Lee, J. C., Robards, K. and Choi, S. H. (2010). Immobilization of tryrosine in carboxylic and carbonyl group-modified MWNT electrode and its application for sensing phenolics in red wine. Journal of Nanoscience and Nanotechnology, 10: 3790-3798.

59. Kirk, O., Borchert, T. V. and Fuglsang, C. C. (2002). Industrial enzyme applications. Current Opinion in Biotechnology, 13: 345-351.

60. Koohmaraie, M. and Geesink, G. H. (2006). Contribution of postmortem muscle biochemistry to the delivery of consistent meat quality with particular focus on the calpain system. Meat Science, 74: 34-43.

61. Law, J. and Haandrikman, A., (1997). Proteolytic enzymes of lactic acid bacteria. International Dairy Journal, 7: $1-11$.

62. Lee, W. C., Yusof, S., Hamid, N. S. A. and Baharin, B. S. (2006). Optimizing conditions for enzymatic clarification of banana juice using response surface methodology (RSM). Journal of Food Engineering, 73: 55-63.

63. Leisola, M., Jokela, J., Pastinen, O., Turunen, $\mathrm{O}$. and Schoemaker, $\mathrm{H}$. (2002). Industrial use of enzymes, In: $\mathrm{H}^{*}$ anninen, O. O. P. and Atalay, M. (Eds.), Encyclopedia of Life Support Systems (EOLSS). EOLSS, Oxford, UK. pp. 1-25,

64. Linko, Y-Y., Javanainen, P. and Linko, S. (1997). Biotechnology of bread baking. Trends in Food Science and Technology, 8: 339-344 
65. Main, G. L. and Morris, J. R. (2007). Effect of Macerating Enzymes and Post fermentation Grape- Seed Tannin on the Color of Cynthiana Wines. American Journal of Enology and Viticulture, 3: 365-372.

66. Martinez-Anaya, M. A., Jimenez, T. (1997). Rheological properties of enzyme supplemented doughs. Journal of Texture Studies, 28: 569583

67. Mehaia, M. A. and Cheryan, (1987). Production of lactic acid from sweet whey permeate concentrates. Process Biochemistry, 22: 185-188.

68. Miller, M. F., Carr, M. F., Ramsey, C. B., Crockett, K. L. and Hoover, L.C. (2001) Consumer thresholds for establishing the value of beef tenderness. Journal of Animal Science, 79: 3062-3068.

69. Minussi, R. C., Pastore, G. M. and Duran, N. (2002). Potential application of laccase in the food industry. Trends in Food Science and Technology, 13: 205-216

70. Mojsov, K. (2013). Use of enzymes in wine making: A review. International Journal of Marketing Technology, 3: 112-127

71. Nelson, M. (2005). The Barbarian's Beverage: A History of Beer in Ancient Europe. Routledge Publication, New York, pp. 1.

72. Norus, J. (2006). Building sustainable competitive advantage from knowledge in the region: the industrial enzymes industry. European Planning Studies, 14: 681-696.

73. Parley, A., Vanhanen, L., and Heatherbell, D. (2001). The effect of pre-fermentation enzyme maceration on extraction and colour stability in Pinot noir wine. Australian Journal of Grape and Wine research, 7: 146-152.

74. Pecket, R. C. and Small, C. J. (1980). Occurrence, location and development of anthocyanoplasts. Phytochemistry, 19: 2571-2576.

75. Plank, P. F. H. and Zent, J. R. (1993). Use of enzymes in wine-making and grape processing, In: Gumpand, B.H. and Pruett, D.J. (Eds.), Beer and Wine Production Analysis, Characterisation, and Technological Advances. American Chemical Society, Washington, D.C.

76. Poulsen, P. B. and Klaus Buchholz, H. (2003). History of enzymology with emphasis on food production. In : Whitaker, J. R., Voragen, A. G. J. and Wong, D. W. S. (Eds.), Handbook of Food Enzymology. Marcel Dekker, New York, pp. 11-20,

77. Revilla, I. and Gonzàlez-SanJosé, M. L. (2002). Addition of pectolytic enzymes: an enological practice which improves the chromaticity and stability of red wines. International Journal of Food Science and Technology, 38: 29-36.

78. Riberiro D. S., Henrique, S. M. B., Oliveira, L. S., Macedo, G. A. and Fleuri, L. F. (2010). Enzymes in Juice processing: A review. International Journal of Food Science and Technology, 45: 224-230

79. Rogerson, F. S. S., Vale, E., Grande, H. J. and Silva, M. C. M. (2000). Alternative Processing of Port-Wine Using Pectolytic Enzymes. Ciencia y Tecnologia Alimentaria, 2: 222-227.

80. Rombouts, F. M. and Pilnik, W. (1980). Pectic enzymes. In: Rose, A. H. (Eds.), Economic microbiology. Academic Press, UK. pp. 227-282.

81. Romero-Cascales, I., FernándezFernández, J. I., Roz-García, J. M., Lópezz-RocaJ. M., and Gómez-Plaza, E. (2008). Charactersation of the main enzymatic activities present in six commercial macerating enzymes and their effects on extracting colour during winemaking of Monstrell grapes. International Journal of Food Science and Technology, 43: 12951305.

82. Sandri, I. G., Fontana, R. C., Barfknecht and Da Silveira, M. M. (2012). Clarification of fruit juices by fungal pectinases. Food Science and Technology, 44: 2217-222 
83. Sanz Penella, J. M., Collar, C. and Haros, M. (2008). Effect of wheat bran and enzyme addition on dough functional performance and phytic acid levels in bread. Journal of Cereal Science, 48: 715-721.

84. Sarioglu, K., Demir, N., Acar, J. and Mutlu, M. (2001). The use of commercial pectinase in the fruit juice industry. Part 2: Determination of the kinetic behaviour of immobilized commercial pectinase. Journal of Food Engineering, 47: 271-274.

85. Schafer, T., Kirk, O., Borchert, T. V. (2002). Enzymes for technical applications. In: S. R. Fahnestock and S. R. Steinb"uchel, (Eds.), Biopolymers. Wiley-VCH, Weinheim, Germany. pp. 377-437.

86. Sheldon, R. A. (2007). Enzyme immobilization: the quest for optimum performance. Advanced Synthesis and Catalysis, 349: 12891307.

87. Siswoyo, T. A., Tanaka, N. and Morita, N. (1999). Effects of lipase combined with $\alpha$-amylase on retrogradation of bread. Food Science and Technology Research, 5: 356-361

88. Stauffer, C. E. (1990). Enzymes. In: Stauffer, C.E. (Eds.), Functional Additives for Bakery Foods. Van Nostrand Reinhold, New York. pp. 148-152.

89. Surowka, K. and Fik, M. (1994) Studies on the recovery of proteinaceous substances from chicken heads: II application of pepsin to the production of protein hydrolyzate. Journal of the Science of Food and Agriculture, 65: 289-296.

90. Synowiecki, J. (2007). The use of starch processing enzymes in the food industry. In: Polaina, J. and MacCabe, A. P. (Eds.), Industrial EnzymesStructure, Function and Applications. AA Dordrecht, The Netherlands. pp. 17,3300

91. The Freedonia Group, Inc.: world food \& beverage enzyme demand by market (million dollars) $2000-2020$ :
Study \#: 2824 - World Enzymes to 2015.

92. Tocchini, R.P. and Lara, J.C.C. 1977. Manufacture of natural and concentrated banana juice. Boletini do Institute de Technologia de Alimentos, Brazil, 51: 93-112

93. van Rensburg, P. and Pretorius, I. S. (2000). Enzymes in wine making: Harnessing natural catalysts for efficient biotransformations: A Review. South African Journal for Enology \& Viticulture, 21: 52-73.

94. Vasic-Racki, D. (2006). History of industrial biotransformations-dreams and realities, In: Liese, A., Seelbach, K. and Wandrey, C. (Eds.), Industrial Biotransformations ( $2^{\text {nd }}$ edn), Wiley$V C H$, Weinheim, Germany. pp. 1-35,

95. Villettaz, J. C. and Dubourdieu, D. (1991). Enzymes in wine-making. In: Fox, P. F. (Eds.), Food Enzymology. Elsevier Science Publishers Ltd, New York

96. Viquez, F., Laetreto, C. and Cooke, R. D. (1981). A study of the production of clarified banana juice using pectinolytic enzymes. International Journal of Food Science and Technology, 16: 115-125.

97. Vollmer, A. N. and Rosenfield, R. G. (1983). Extraction of protein from pork bones. US patent 4402873.

98. 100. Ward, O. and Moo-Young M. (1988). Thermostable enzymes. Biotechnology Advances, 6: 39-69

99. 101. Watson, B., Goldberg, N., Chen, H. P., McDaniel, M. and Price, S. (1999b). Effects of macerating pectinase enzymes on color, phenolic profile, and sensory character of Pinot noir wines. Cooperative extension 2nd point Burgundy-California-Oregon Winemaking Symposium. February 89.

100. 102. Webster, J. D., Ledward, D. A. and Lawrie, R. A. (1982). Protein hydrolyzates from meat industry byproducts. Meat Science, 7: 147-157.

101. 103. Whitaker, J. R. (1984). Pectin substances, pectin enzymes and haze 
formation in fruit juices. Enzyme Microbial and Technology, 6: 341349.

102. 104. Whitehurst, R. J. and van Oort, M. (2010). Enzymes in meat processing. In: Enzymes in Food Technology ( $2^{\text {nd }}$ edn)., John Wiley \& Sons, Ltd., United Kingdom

103. 105. Whitehust, R. J. and Law, B. A. (2002). The nature of enzymes and their action in foods, In: Enzymes in Food Technology. Sheffield Academic Press, UK.

104. 106. Yamamoto, S., Imamura, A., Susanti, I., Hori, K., Tanji, Y. and Unno, H. (2005). Effect of spacer length on beta-lactoglobulin hydrolysis by trypsin covalently immobilized on a cellulosic support. Food and Bioproducts Processing, 83: 61-67

105. 107. Yokobayashi, K., Misaki, A. and Harada, T. (1970) Purification and properties of Pseudomonas isoamylase. Biochimica et Biophysica Acta, 212: 458-469.

106. 108. Zór, K., Ortiz, R., Saatci, E., Bardsley, R., Parr, T., Csöregi, E. and Nistor, M. (2009) Label free capacitive immunosensor for detecting calpastatin - a meat tenderness biomarker. Bioelectrochemistry, 76: 93-99. 